\title{
Foreign Language Study
}

\author{
- Its Relation to the Humanities -
}

\author{
Shinichi OISHI \\ Division of English Language, School of Medicine, University of Occupational and \\ Environmental Health, Japan. Kitakyushu 807, Japan
}

\begin{abstract}
The purpose of foreign language studies is to help the student increase his ability in speaking, comprehending, reading, and writing a foreign language. For most Japanese medical students, university studies in English are a continuation of six years of junior and senior high school English. For other languages, such as German and French, it is the beginning of a study which may continue for only two years or may be the cause of a lifelong interest in the language. No matter what the language may be or what level a student may attain, the primary purpose of any foreign language is to communicate with a person from another culture orally or through the written language as a dispenser or receiver of knowledge. Effective communication in a foreign language implies that one knows not only the language but also the culture and customs of the foreign country and how to develop human relationships with a person from this culture. The foreign language teacher can help the student to attain this knowledge but much can also be learned by studying the subjects taught under the humanities. In this paper, I attempt to show reasons why the humanities and foreign language studies are both necessary to develop good communicators and propose that the teachers of the humanities and foreign languages work closely together to develop international persons.
\end{abstract}

Key words: foreign languages, humanities, communication, human element, medical student.

(Received 14 September 1984)

\section{Introduction}

In most if not all Japanese medical school curriculums, foreign languages are separated from General Education, under which the humanities are found, leaving one with the impression that foreign languages and the humanities are distinct branches of learning. The purpose of this paper is not to advocate the complete amalgamation of the humanities and foreign languages but to show that subjects studied under the humanities can be of great help in mastering a foreign language, and even though the two branches of learning may remain under separate headings, those involved in teaching these subjects should work together in preparing and overall set of courses that will help the medical student to step confidently into an international situation if the occasion arises in his future. 


\section{Foreign Language Study}

The primary purpose of foreign language courses is to train a student to communicate with a person from another culture either orally or through the written language and to be able to increase one's knowledge through the reading of foreign books and periodicals. This purpose implies that the student develops a working vocabulary and sufficient grammar to express himself, time for practice in both the spoken and written language, as well as comprehension. However, is this all there is to the study of foreign languages? I am sure you will agree with me that one important part of communication, namely, the human element, is missing. The study of communication, whether it is in the form of oral or written language, if it neglects this element, will hinder rather than help a student attain fluency in communication.

\section{The Human Element}

\section{Commonality}

The key to delving into the human element of a language is the word, communication. Human communication simply means that a person is involved in communication either as a sender of ideas, a receiver of ideas, or both a sender and a receiver. This definition can be applied to communication other than oral but in this paper I want to confine my remarks to oral communication between two or more people. Robert G. King in his book, Fundamentals of Human Communication, states, "If the communicators share a common background, common beliefs, common values, common attitudes, a common language, and common meanings, they have a basis for successful communication." (p. 6) All of these conditions may be present when those communicating belong to the same culture but even persons from the same culture who possess only some of the above conditions could, because of different backgrounds, interests, educational levels etc., have difficulty communicating over a long period of time. It follows then that if persons of the same culture may have difficulty in communicating because of the lack of some of the conditions mentioned in King's definition, those from different cultures will be faced with more formidable obstacles unless they prepare themselves by study to learn not only another person's language but also the culture, customs and beliefs in which the person has been raised. The teacher of foreign language courses through his choice of textbooks for reading classes helps the student in attaining a basic knowledge of foreign cultures, customs and beliefs but if the humanities included courses in foreign literature, history, political science, religion and sociology the student would acquire a deeper knowledge of the culture, customs etc. of foreign countries and thereby be able to communicate more effectively with the foreign nationals he meets. Also, if the teachers of these courses met with the foreign language teachers regularly with the idea of both setting up a 
curriculum that would have the common purpose of preparing the medical student to be able to take his place in the international community, and of comparing notes on the progress of the students, then I think the student may have a clearer view of his first two years in medical school and see it as a very important part in his preparation for the medical profession.

Individuality

Another point one must consider when communicating is that human communication implies people who may be from the same or different culture but because of their personalities are quite different from one another. To be a good communicator, whether within your own culture or with a person from another culture, you must first of all know yourself. What kind of person are you? What are your faults and what are your good points? What is necessary to develop true human relationships? The study of these questions falls under the heading of philosophy, so therefore it follows, I believe, that philosophy and foreign language studies should, to a certain extent, go hand in hand. Furthermore, as the good communicator must also be a good judge of an individual's emotional and behavior characteristics, the study of psychology will also be an aid to more effective communication. I am not implying here that philosophy and psychology courses should be completely geared to making a person a more efficient communicator, but, as mentioned above, if there is some coordination between the teachers of philosophy, psychology and foreign languages, a more effective curriculum may come into existence.

\section{The Foreign Language Teacher}

What I have said above under Individuality can be applied to communication between people of the same culture. However, when we consider communication between people of different cultures we must take what I have said one step further and this is the work of the foreign language teacher. Courses on history, literature, culture and customs of other countries can be taught under the humanities but it is the work of the foreig language teacher to take these subjects and apply them to an intercultural situation. This presumes that the foreign language teacher has a fair knowledge of the culture in which the language he is teaching is used and that his choices of reading textbooks should contain material that will not only help the student master a foreign language but will also give him a deeper. knowledge of the country and people who speak that language.

This knowledge of a person's culture is very important when communicating. To be a successful communicator in a foreign language you must have a good knowledge of when and to whom you should use certain words, the special meaning given by an intonation or inflection on a word, the meaning of gestures, facial expressions and body movements, or in short, a knowledge of the body language of the culture of the person to whom you are speaking. In other words, we convey ideas not just by words but by our whole attitude, 
and when there is a lack of knowledge of how to present our whole self to an individual raised in another culture or if we are unable to comprehend the messages he gives through body language, mistakes are bound to be made in intercultural communication.

The following two stories should make my point clearer. Some years ago I attended a reception at a company for the representative of the main office in Tokyo. This man had spent many years in the United States and was very good in English. When he met me, because I was born and raised in Canada, we conversed in English. After a few minutes I found myself very uncomfortable with him. It was not his language but his attitude that made me want to get away from him. He was very boisterous and, for me, quite overbearing. After we had been talking for about ten minutes, or I should, say, he had been talking and I had been sending signals of dislike through body language, the president of the company joined us and as he could not speak English the conversation continued in Japanese. When this representative spoke in his native language he was a completely different person, one that I liked very much. This gentleman down through the years, when he spoke in English, had developed habits which he may have thought were typical American but in the process he had lost many of the niceties of his own culture and had failed to adopt some of the accepted customs of the American culture. The foreign language teacher therefore must always be on his guard that this trait does not develop in his students, especially those who may have spent a short time in a foreign country or have become quite proficient in the language.

The second story has to do with a problem that is becoming more common in Japan with each passing year. A few years ago, a young friend of mine who was an English teacher here in Japan, had been teaching English all day and on his way home on the train, found himself sitting across from a young lady about his own age. As he was studying Japanese very diligently in his spare time, he thought that this would be a pleasant chance to speak in Japanese. He said to the girl, "Doko made desu ka?" She answered, in English, "T'm going to ......" My friend became a little angry as the answer he received by her replying in English could imply, depending on his mood and how tired he was, "You don't have to speak Japanese as I understand English" or he may have even taken from it the meaning "Please speak to me in English as your Japanese is not very good." However, he persevered and tried again, unfortunately, with the same result. He then saw the futility of trying to speak in Japanese so he spoke to her for a while in English and then took out the novel he usually read on trains and began to read. This young lady likely had no intention of hurting my friend's feelings, after all, she wanted to practice her English as much as he wanted to practice his Japanese, but if she had only realized that his question in Japanese was conveying to her the desire to speak in Japanese and if she had answered him in Japanese, a conversation could have evolved in which probably both of them could have satisfied their desire to speak in each other's language.

Therefore, as communication in a foreign language involves much more than just 
mastering the spoken language it follows that the foreign language teacher must be prepared to help the student to express a pleasant attitude to a person of another culture and to be able to comprehend the overall message that this person is giving him. Again, the foreign language teacher can prepare himself much better by having close contact with the teachers of the humanities and exchanging ideas with them.

\section{Conclusion}

The ideas presented in this paper may seem too idealistic but if a student entering medical school sees that his foreign language courses are linked through subject matter to his courses in the humanities and that one aim of both the humanities and foreign language courses is to help him become an international person, I think that many of the students would take a more active interest in the various subjects.

Those in charge of making up the curriculum may say that it is next to impossible to work all the various subjects mentioned in this paper into a curriculum but I think if more elective subjects were added to the humanities curriculum and part-time teachers were hired to teach the subjects, the problem could be solved.

It is impossible to say how many of the present-day medical students will be involved in medicine on the international scene but as we rush toward the 21 st century, I believe that those of us involved in training medical students must prepare them for the eventuality that they may have to work with members of the medical profession from other cultures. There are many ways to prepare the student for this eventuality, but it is through the close cooperation of the foreign language teachers and those of the humanities that courses will be established that will go a long way in the preparation of medical students to take their place on the international stage. This paper is not advocating radical changes in the curriculums of medical schools, although, I would personally like to see foreign languages included under General Education in the curriculums, but it is written with the hope that the teachers of foreign languages and the humanities will have close contact within their university and that occasional meetings will take place in which teachers in these two fields from various universities can exchange ideas on the points mentioned in this paper.

\section{References}

Barnlund, D. C. (1975): Public and Private Self in Japan and the United States. The Simul Press, Tokyo.

Brislin, R. W. (1981): Cross-Cultural Encounters. Pergamon Press Inc., Elmsford, New York.

Condon, J. C. \& Yousef, F. (1978): An Introduction to Intercultural Communication. Bobbs and Merrill Educational Publishing, Indianapolis.

Fast, J. (1971): Body Language. Pan Books, London. 
Hall, E. T. (1973): The Silent Language. Anchor Books, Garden City, New York.

King, R. G. (1979): Fundamentals of Human Communication, Macmllan Publishing Co., Inc., New York.

外国語学習一人文科学との関連性一

大石真一

産業医科大学英語学教室

要旨: 外国語研究の目的は, 外国語を読み, 理解し, 話し, 書く能力を学生に身につけさせるこ とである. 日本の大半の医学生にとって, 大学での英語の学習は 6 年間の中学・高校の英 語教育の継続である. 独語, 仏語といった他の外国語の場合は, 新たに学習を開始するこ とになるが，それはわずか 2 年間で終ることになるかもしれないし，一生涯その外国語に 関心を持ち続ける出発点となるかもしれない，学習する外国語のいかんにかかわらず，ま た学生がよ゙のレベルにまで到達するかにかかわらず, 外国語学習の第一の目的は, 異文化 を持つ人との間に口頭または文章を通して知識の受理者ないしは提供者として意志の伝達 を行うことである．外国語での効果的意志の伝達とは, その伝達者が当該言語を知ってい るというだけでなく，当該国の文化，習慣を知っているということであり，その文化を持 つ国の人と人間関係を発展させていくすべを知っているということである.外国語教師は, このような知識を習得しようとする学生の手助けをすることができるし，また，人文科学 系の科目を勉強することによっても多くのことを学ぶことができる．本稿では，上手な意 志の伝達者を育成するのになぜ人文科学系の科目と外国語研究の双方が必要なのか, その いくつかの理由を明らかにすると同時に，人文科学系の教師と外国語教師の双方が国際人 を育てるために密接に協同すべきことを提唱する.

J. UOEH（産業医大誌），6（4)：437-442(1984) 